\title{
Herbivore response to anti-quality factors in forages
}

\author{
K.L. LAUNCHBAUGH, F.D. PROVENZA, AND J.A. PFISTER
}

Authors are assistant professor, Rangeland Ecology and Management Dept., University of Idaho, Moscow, Ida. 83844; professor, Rangeland Resources Dept., Utah State University, Logan, Utah. 84322; and, research scientist, USDA-ARS Poisonous Plants Research Laboratory, Logan, Utah 84341.

\begin{abstract}
Plants possess a wide variety of compounds and growth forms that are termed "anti-quality" factors because they reduce forage value and deter grazing. Anti-quality attributes can reduce a plant's digestible nutrients and energy or yield toxic effects. Herbivores possess several adaptive mechanisms to lessen the impacts of anti-quality factors. First, herbivores graze selectively to limit consumption of potentially harmful plant compounds. Grazing animals rely on a sophisticated system to detect plant nutritional value or toxicity by relating the flavor of a plant to its positive or negative digestive consequences. Diet selection skills are enhanced by adaptive intake patterns that limit the deleterious effects of plant allelochemicals; these include cautious sampling of sample new foods, consuming a varied diet, and eating plants in a cyclic, intermittent, or carefully regulated fashion. Second, grazing animals possess internal systems that detoxify or tolerate ingested phytotoxins. Animals may eject toxic plant material quickly after ingestion, secrete substances in the mouth or gut to render allelochemicals inert, rely on rumen microbes to detoxify allelochemicals, absorb phytochemicals from the gut and detoxified them in body tissues, or develop a tolerance to the toxic effects of plant allelochemicals. Understanding the behavioral and metabolic abilities of herbivores suggests several livestock management practices to help animals contend with plant anti-quality characteristics. These practices include offering animals proper early life experiences, selecting the appropriate livestock species and individuals, breeding animals with desired attributes, and offering nutritional or pharmaceutical products to aid in digestion and detoxification.
\end{abstract}

Key Words: anti-quality, conditioned aversions, detoxification, diet selection, forage quality, foraging, grazing behavior, toxic plants

Forage "quality" is the collective assessment of a plant's ability to contribute to growth and production of grazing animals. Rangeland forages usually also contain compounds that limit or adversely affect animal production. These attributes are termed "anti-quality" because they restrict "quality" in some way. Implicit in this delineation is the idea that quality and anti-quality parameters are measured by animal response. The grazing value of a specific forage cannot be determined by a few simple laboratory procedures because grazing animals possess a variety of

The publication was made possible by the Grazing Lands Technology Institute of the Natural Resources Conservation Service, Fort Worth, Texas 76115

Manuscript accepted 27 Nov. 00.

\section{Resumen}

Las plantas poseen una amplia variedad de compuestos $y$ formas de crecimiento que son llamadas factores "anti-calidad" porque reducen el valor del forraje y desalienta el apacentamiento de ellas. Los atributos anti-calidad pueden reducir los nutrientes y energía digestibles de la planta o producir efectos tóxicos. Los herbívoros poseen varios mecanismos adaptativos para aminorar los impactos de los factores anti-calidad. Primero, los herbívoro apacientan selectivamente para limitar el consumo de compuestos vegetales potencialmente dañinos. Los animales en apacentamiento dependen de un sistema sofisticado para detectar el valor nutricional o la toxicidad de las plantas relacionando el sabor de la planta con sus consecuencias digestivas positivas o negativas. Las habilidades para seleccionar la dieta aumentan por los patrones adaptativos de consumo que limitan los efectos perjudiciales de los aleloquímicos de la planta, estos incluyen la precaución de probar nuevos alimentos, consumiendo una dieta variada y comiendo plantas de una manera cíclica, intermitente o cuidadosamente regulada. Segundo, los animales en apacentamiento poseen sistemas internos para detoxificar o tolerar la ingestion de fitotoxinas. Los animales pueden expulsar rápidamente el material vegetal toxico después de la ingestión, segregan substancias en la boca o el intestino para hacer inertes a los aleloquímicos, dependen de los microbios ruminales para detoxificar los aleloquímicos, absorber los fitoquímicos del intestino y detoxificarlos en los tejidos corporales o desarrollar una tolerancia a los efectos tóxicos de los aleloquimicos de la planta. El entendimiento de las habilidades de comportamiento y metabólicas de los herbívoros sugiere varias prácticas de manejo del ganado para ayudar a los animales a contender con las características anti-calidad de las plantas. Estas prácticas incluyen el ofrecer a los animales experiencias apropiadas durante las primeras etapas de su vida., seleccionar las especies e individuos de ganado mas apropiados, criar animales con los atributos deseados y ofrecer productos nutricionales o farmacéuticos que auxilian en la digestión y detoxificación.

dietary and metabolic mechanisms to exploit plant nutrients and overcome the negative effects of anti-quality attributes. Successful livestock management on rangelands requires an understanding of plant nutritional content and potential effects of anti-quality attributes. However, managers must also be cognizant of the skills herbivores possess to harvest nutrients and avoid toxins. In this paper, we will examine how anti-quality plant attributes affect diet selection and intake. We will also examine the behavioral and digestive strategies that animals 
employ to overcome the anti-quality aspects and gain access to the nutrient and energy resources of plants. Finally, we will suggest management approaches to help animals contend with anti-quality attributes in forages.

\section{Anti-quality Attributes Affect Diet Selection Through Digestive Consequences}

Grazing animals are unquestionably sensitive to the quality and anti-quality attributes of plants. For example, animals select diets of higher quality than the average forage available (Arnold 1981, Provenza 1995). Animals also limit their consumption of toxins by selecting plants and plant parts of relatively low toxin concentration (Provenza 1995, Pfister 1999). How animals sense the quality or toxicity of forages has been an active area of research for more than 3 decades. It is now clear that animals ascribe forage value by relating plant flavor to positive or negative digestive consequences (Provenza 1995, 1996). Grazing decisions are based on a series of interrelated and cumulative consequences of consumption.

A plant's chemical and structural attributes dictate its digestive consequences because they set the potential digestible energy, nutrient yield, or toxicity of the plants. The digestion and detoxification abilities of grazing animals, and their microbial symbionts, determine the actual yield of nutrients, energy, or toxins. The results of these plant and animal interactions determine a forage's palatability or hedonic value (i.e., pleasurable and disagreeable sensations experienced through taste and smell). Palatability, in turn, affects the probability that the plant will

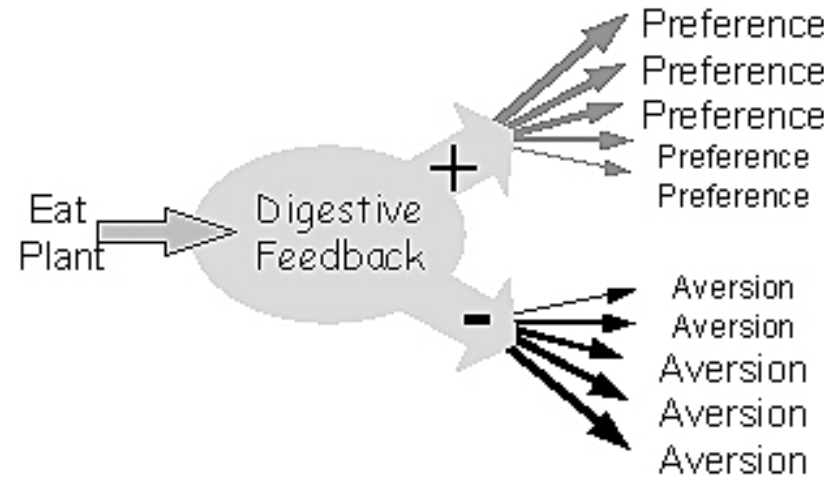

Fig. 2. When an animal eat a plant it receives digestive feedback in the form of energy, nutrients, illness, or toxicosis. If the feedback is positive, preferences are formed to the plant and if the feedback is negative, aversions are formed. The strength of the preference or aversion is determined by the magnitude, nature, and timing of digestive feedback. be eaten in future encounters. The key to how animals respond to anti-quality factors in plants is therefore centered on the consequences of consumption (Fig. 1).

When a grazing animal smells and tastes a plant, the flavor is either pleasing or distasteful depending on the animal's previous grazing experiences. If the plant is new to the animal, its initial hedonic value depends on its similarity to familiar plants. Grazing animals tend to consume new foods that are similar to preferred foods and avoid new foods that are similar to foods they dislike (Launchbaugh and Provenza 1993, Provenza et al. 1999). When a plant is eaten, it provides feedback during digestion and metabolism. The flavor (i.e., taste and odor) of a plant becomes more or less pleasing to the animal depending on digestive consequences. If consumption of a plant improves the nutrient or energy status of the animal, the plant flavor becomes more desirable or pleasing to the animal. If consumption of the plant yields illness or digestive malaise, the flavor becomes aversive and

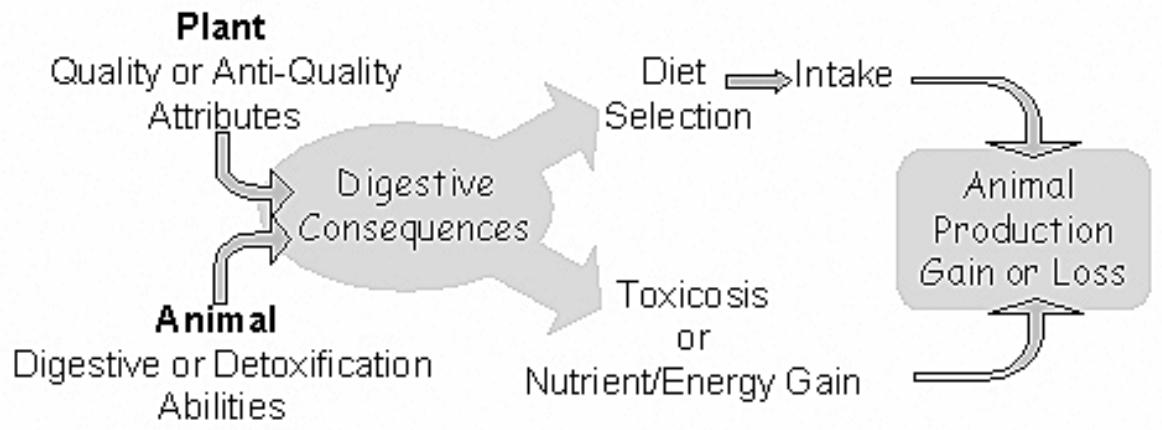

Fig. 1. Digestive consequences are at the center of how animals respond to anti-quality factors in forages. The actual digestive feedback animals receive is determined by plant forage quality and animal digestive and detoxification abilities. The consequences of consumption, in turn, affect diet selection and intake and the nutrients and energy available for animal growth and maintenance. distasteful (Fig. 2). This is known as a hedonic shift. This "evaluation" system is based on processes occurring at a sub-conscious level that selectively relate gastrointestinal feedback with the flavor, rather than the sight or texture, of a food (Garcia 1989, Provenza 1995). These flavor-consequence relationships form the basis for dietary likes and dislikes.

Once the hedonic value of a plant is established, the animal uses its senses of smell and sight to differentiate between plants and seek foods with high hedonic value and avoid aversive foods. Searching and selective grazing are cognitive processes that can be further reinforced by interactions with other animals (Thorhallsdottir et al. 1990a, 1990b). The resulting behavior patterns lead to increased consumption of foods that are likely to yield nutritional benefit and limited consumption of toxic or low quality plants.

Grazing preference also depends on the animal's nutritional state (Provenza 1995, Provenza et al. 1998). When need for a nutrient is high, preferences for foods containing the nutrient are high. When needs are met, preference declines. For example, lambs fed diets of inadequate sodium, energy, or protein show a strong preference for foods high in sodium, energy, or protein, respectively (Villalba and Provenza 1996, 1999). Thus, an animal's nutritional state influences its incentive to seek and eat particular plants.

\section{How Plant Anti-quality Attributes Drive Diet Selection and Intake}

Plants possess a wide variety of chemical and physical properties that reduce forage value and serve as grazing deterrents. 
From the animal's perspective, the effects of anti-quality attributes can be expressed along a continuum from those that reduce the forage nutrient or energy yield to those producing toxic or ill effects. How strongly a plant attributes affects diet selection or intake therefore depends on the magnitude, timing, or nature of digestive feedback (Fig. 2).

\section{Reduce Digestive Benefits}

Herbivores can quite effectively distinguish between plants that differ in digestible energy or nutrients (Villalba and Provenza 1996, 1997a, 1997b). Lambs formed strong preferences for flavored straw when consumption was followed by ruminal infusions of starch (Villalba and Provenza 1997a, Smith et al. 1999), volatile fatty acids (Villalba and Provenza 1996, 1997b), or protein sources (Villalba and Provenza 1997c). Preference for most rangeland forages is positively correlated with digestive benefits (Arnold and Hill 1972, Arnold 1981). Phytochemicals that reduce the potential digestive yield of a plant can therefore be viewed as anti-quality factors. For example, lignin (Van Soest 1994), tannins (Reese 1979), and resinous compounds (Meyer and Karasov 1991) can reduce forage digestibility by forming insoluble complexes with nutrients. High content of indigestible compounds, such as silica and waxes, can dilute the digestive gain of a plant and reduce preference (Herms and Mattson 1992). Plant digestibility can also be reduced by allelochemicals that inactivate digestive enzymes or harm gut microbes. For example, a wide variety of plants including, potatoes (Solanum tuberosum L.), soybeans (Glycine max [L.] Merr.), cottonseeds (Gossypium L.), and tomatoes (Solanum lycopersicum L.) contain trypsin and chymotrypsin inhibitors that can interfere with protein digestion, particularly in monogastric animals (Reese 1979, Slansky 1992). Compounds that precipitate proteins, like gossypol (Slansky 1992) and tannins (Reese 1979, Robbins et al. 1991), can also decrease digestibility by binding and inactivating digestive enzymes. Allelochemicals also have anti-microbial effects that inhibit rumen or cecal/colon microbes thereby reducing digestibility (Allison 1978).

The magnitude of digestive feedback can strongly affect intake and preference; however, the rate at which nutrients or energy are liberated may also be important. Sheep prefer foods paired with ruminal energy infusions immediately after consumption to those paired with delayed infusions of energy (Villalba et al. 1999, Smith et al. 1999). A high content of structural carbohydrates, such as cellulose or hemicellulose, in plants may have little effect on the extent of digestion and yet reduce preference and intake by delaying the digestive gain of plant material.

\section{Create Toxic Effects and Food Aversions}

Many allelochemicals in rangeland and pastureland plants cause a variety of deleterious neurological, metabolic, and terratogenic effects and are therefore termed toxic. For discussions on the toxic effects of plant compounds refer to other papers in this volume or a recent review by Cheeke (1998). These toxic effects can cause severe production losses and yet not alter diet selection or intake. Strong flavor aversions are observed only when a phytotoxin stimulates the emetic centers of the midbrain and brainstem that control nausea and vomiting (Grant 1987, Garcia 1989, Provenza et al. 1992, 1994a, Provenza 1995). Herbivores can readily form aversions to feeds that stimulate the emetic system, however they may not be able to avoid feeds that do not cause nausea (e.g., cause allergies, bloating, or lower intestinal discomfort; Garcia 1989, Provenza et al. 1992). Further evidence to the important role of the emetic system is that anti-emetic drugs can attenuate lithium chloride-(Provenza et al. 1994a) and alkaloid-induced (Aldrich et al. 1993) aversions in sheep.

Aversive post-ingestive feedback causes cattle, sheep, and goats to decrease intake of foods containing toxins such as alkaloids in larkspur (Delphinium spp.; Pfister et al. 1997) and tall fescue (Festuca arundinaceae Schreb.; Aldrich et al. 1993), condensed tannins in blackbrush (Coleogyne ramossisma Torr.; Provenza et al. 1990), essential oils in big sagebrush (Artemisia tridentata Nutt.; Fraker 1999) and juniper (Juniperus spp.; Pritz et al. 1997), and allelochemicals in mesquite (Prosopis glandulosa Torr.; Baptista and Launchbaugh 2001). Conditioned aversions may be mild (i.e., temporary) or strong (i.e., permanent) depending on the toxin dose and when and how the toxin affects the gut and brain. Doses of allelochemicals that make animals intensely ill form stronger aversions than weak emetic stimulants (Ralphs and Cheney 1993, Launchbaugh and Provenza 1994). To form lasting aversions, consequences must be experienced within 8 hours of consumption (Burritt and Provenza 1991). It is difficult, if not impossible, for animals to learn to avoid a nutritious food that yields toxic effects several days or weeks after consumption. There are several examples in nature where animals prefer less toxic or nontoxic plants apparently because they produce less negative gastro-intestinal consequences upon consumption than alternatives (Provenza 1995, Pfister 1999).

Aversions can also be formed to foods that are not commonly considered "toxic". Soluble carbohydrates or nitrogen content of some feeds or forages can be so dense as to cause gastro-intestinal malaise when eaten in excessive amounts. For example, ruminants often form aversions to fruits and grains because excessive energy consumption can cause illness (Provenza 1995). Aversions have been demonstrated when high doses of energy supplements, such as propionate, were administered to sheep during a meal (Ralphs and Cheney 1993, Villalba and Provenza 1996). Ruminants eating foods high in rumendegradable protein can also experience high levels of ruminal ammonia, suffer malaise, and decrease intake (Prins and Beekman 1989, Villalba and Provenza 1997c).

\section{How Animals Contend with Anti-quality Factors}

To live a healthy life on rangeland, herbivores must consume nutritious plants and avoid toxic or low quality plants. Foraging animals face the challenge of obtaining nutritious diets in environments where nutritional value and toxicity vary greatly from plant to plant, place to place, and time to time. To meet this challenge, herbivores possess several adaptive behavioral mechanisms that limit toxins and increase nutrients ingested, and internal systems that detoxify or tolerate ingested phytotoxins.

\section{Selective Grazing}

Selective grazing is the herbivore's first line of defense against the negative effects of plants with toxins or anti-quality attributes (Launchbaugh 1996). To make wise grazing decisions, animals must either be born knowing what to eat or avoid, learn appropriate dietary habits from peers, or learn from individual experiences. Diet selection strategies employed by herbivores have been reviewed in several publications (Provenza et al. 1992, 1998, Launchbaugh 1996, Provenza 1995, 1996, Pfister 1999, Foley et al. 1999). The following discussion provides an overview with reference to animal responses to antiquality factors in plants. 


\section{Instinctive Avoidance}

Some researchers contend that animals are instinctively attracted to sweet flavors and repelled by bitter flavors (Rhoades 1979, Owen 1992). Many plant toxins supposedly taste bitter (e.g., saponins and cyanogenic glycosides), have offensive odors (e.g., terpenes), or provoke an astringent sensation when eaten (e.g., tannins); however, these attributes are not universally repellent (Glendinning 1994). Sheep (Arnold and Hill 1972) and cattle (Pfister et al. 1996) do not necessarily avoid bitter tastes nor do sheep form stronger aversions to bitter than to sweet flavors (Launchbaugh et al. 1993). Furthermore, animals acquire preferences for bitter and sour flavors when consumption is followed by calorie enhancement even when these flavors were not initially preferred (Sclafani 1991). There is considerable evidence questioning the existence of an innate recognition system for plant nutritional or toxic qualities based on flavor or any other plant quality.

\section{Learning from Mother and Peers}

Livestock live in multi-generational groups in which dietary information can be easily passed from experienced to inexperienced animals. Young livestock therefore do not require perfect and complete dietary information at birth. Learning from mother may even begin before young herbivores, take their first bites. Flavors in uterine fluid can influence food aversions (Smotherman 1982). Mother's milk is also a source of information for young livestock. Nolte and Provenza (1992) found that orphan lambs raised on onion-flavored milk preferred onion-flavored feed later in life. Lambs quickly lean to avoid harmful novel foods their mother was trained to avoid, and to consume novel alternatives consmed by mother (Mirza and Provenza 1990, 1994). Nursing calves began to eat substantial quantities of locoweed (Oxytropis spp.; Pfister, unpublished observations) and low larkspur (Delphinium nuttallianum Pritz.; Pfister and Gardner 1999) on the same day as their grazing mothers; suggesting that calves mimicked their mother's diet. Young livestock can also learn appropriate food choices from other adult animals and peers (Thorhallsdottir et al. 1990a, 1990b).

Animals are, however, more influenced by their own dietary experiences than by mother or other social models. Lambs consistently avoided a food after experiencing toxicosis even if their mothers readily consumed the food (Provenza et al. 1993, Pfister et al. 1993). Calves that initially ate larkspur with their mothers, sharply curtailed consumption a few days later (Pfister and Gardner 1999), perhaps because of adverse feedback (Pfister et al. 1997). Nonetheless, social facilitation can play a significant role in ameliorating aversions. Ewes and lambs averted to a pelleted ration ingested more of the ration when feeding with non-averted peers than when feeding alone (Thorhallsdottir et al. 1990a). Cattle also consumed more of a toxic plant they had been conditioned to avoid when feeding with non-averted peers (Lane et al. 1990). Likewise, lambs form stronger aversions to a palatable shrub when exposed to the shrub with other lambs that avoid the shrub than when eating with peers that consumed the shrub (Provenza and Burritt 1991).

\section{Individual Learning about Plant \\ Allelochemicals}

Conditioned aversions are powerful mechanisms by which animals learn to identify and avoid toxic plants (Garcia 1989, Provenza et al. 1992). Many rangeland plants contain compounds that produce aversions if eaten in sufficient quantities, as discussed above. Aversions can be easily demonstrated by offering an animal a single novel food and inducing gastro-intestinal illness immediately following ingestion; however, generalist herbivores rarely eat 1 plant per feeding bout (Westoby 1978). Several mechanisms enable herbivores to attribute digestive effects to specific plants rather than to all the plants in a meal. One way herbivores apparently accomplish this task is by regarding unfamiliar plants with caution. When consuming mixed meals of familiar and novel foods, herbivores preferentially form aversions (Burritt and Provenza 1989, 1991) or preferences (Provenza et al. 1999, Villalba and Provenza 2000) to novel dietary items. For example, when lambs experience toxicosis after eating a meal of 4 familiar and 1 novel food they subsequently avoided only the novel food (Burritt and Provenza 1991). When foraging bouts include several novel plants, plants that dominate the diet are probably 'weighted' more than less consumed plants, even if the minor foods were responsible for more positive or negative feedback (Provenza et al. 1994b). Furthermore, digestive feedback begins quickly after consumption and flavorfeedback interactions during a feeding bout could help animals attribute digestive benefits or liabilities to specific plants. Finally, grazing livestock on rangelands are usually quite familiar with the forage resource and may seldom encounter truly novel plants. This allows greater opportunity to 'sort out' feedback from individual or similar groups of plant species. Collectively, these mechanisms enable herbivores to discriminate among foods within a meal.

\section{Adaptive Intake Patterns}

Sorting out the quality and anti-quality attributes of forages requires keen diet selection skills by the herbivore. Successfully navigating the temporal and spatial variation of forage quality in grazing environments can be accomplished by knowing how much to eat, when to eat, and what else to eat.

\section{Selecting a Varied Diet}

Grazing animals have a strong natural propensity to select diets composed of several plant species and sample available plants on a regular basis. This behavior may increase the likelihood of ingesting necessary nutrients (Westoby 1978) and reduce the potential of overingesting toxins (Freeland and Janzen 1974). Plants contain an immense array of allelochemicals, most of which are toxic if consumed in substantial quantities (Cheek 1998). However, plants with toxins also contain varying kinds and amounts of nutrients. Thus, diet selection among toxic plants is a tradeoff between nutrient gain and potential toxicity (Freeland 1991, Provenza 1996). Mammalian herbivores possess many metabolic pathways to detoxify phytotoxins, but each pathway is generally specific to a single or a group of phytotoxins. Some scientists have suggested that by eating a variety of plants, animals spread the ingestion of toxins over several detoxification pathways (Freeland and Janzen 1974, Freeland 1991). Varied diets may also increase the amounts of some toxic foods that can be eaten because of interactions between allelochemicals that reduce toxicity (Freeland et al. 1985, Launchbaugh 1996).

\section{Cyclic and Intermittent Intake}

The toxic effects of a plant are determined largely by the amount eaten; but, the ingestion rate may also be important. Grazing animals can avoid toxicoses by limiting their consumption of a specific toxic plant each day to allow sufficient time for detoxification (Foley et al. 1995, 1999). For example, lambs limit intake of the toxin lithium chloride as a function of the amount of lithium chloride infused into their rumen before a meal (Wang and Provenza 1997). Animals might also vary 
toxic plant consumption daily to limit potential cumulative effects of specific toxins. Field studies with tall larkspur (Delphinium occidentalis S. Wats.) revealed that consumption above $25-30 \%$ of the diet for 1 or 2 days led to reduced consumption on subsequent days (Pfister et al. 1988). In pen studies, cattle responded to larkspur dosing with distinct cycles of food intake such that 1 to 3 days of higher consumption were followed by 1 to 3 days of reduced consumption (Pfister et al. 1997). Cattle have a dose-response threshold of 14 to $18 \mathrm{mg}$ of toxic alkaloid/kg body weight, so periods of reduced consumption below this threshold probably allowed animals to recover from the larkspur-induced illness.

\section{Regulating Intake of Plant Allelochemicals}

Many allelochemicals may impart a distinct flavor to plants. When plant flavor and toxicity are highly correlated, herbivores apparently regulate food intake based on post-ingestive feedback and then adjust intake based on flavor intensity (Launchbaugh et al. 1993). This may explain how animals commonly choose among plant parts, individuals, or populations to select bites with lower than average amounts of phytotoxins. This behavior, summarized by Pfister (1999), has been observed to minimize consumption of cyanide (in sudangrass, Sorghum bicolor [L.] Moench ssp. drummondii [Nees ex Steud.] de Wet \& Harlan; and bracken fern, Pteridium aquilinum [L.] Kuhn), tannins (in blackbrush), alkaloids (in lupine, Lupinus spp.; reed canarygrass, Phalaris arundinaceae L.; and, tall fescue), and terpenes (in sagebrush, Artemisia spp.). Flavor may not, however, always be a good indicator of toxicity. If toxicity changes without a change in flavor, herbivores are likely to overingest toxic plants because they are not "warned" by a flavor cue. When lambs were offered a feed with a constant flavor and variable toxic feedback, they consumed an amount based on the maximum, rather than the average, dose of the toxin (Launchbaugh et al. 1993). This response reduced the risk of lambs over-ingesting a toxin even when toxicity changes were not accompanied by flavor changes.

\section{Detoxification and Tolerance}

Animals possess several mechanisms to negate or restrict the toxic effects of plant allelochemicals once ingested. Animals may eject toxic plant material quickly after ingestion, secrete substances in the mouth or gut to render allelochemicals inert, rely on rumen microbes to detoxify allelochemicals, or absorb phytochemicals from the gut and then detoxify them in body tissues. Additionally, animals can build a tolerance to the toxic effects of some plant allelochemicals. Much has been written about animal abilities to detoxify plant substances. For more detailed reviews, see Freeland and Janzen (1974), Allison (1978), Brattsten (1979), McArthur et al. (1991), Smith (1992), and Cheeke (1998).

\section{Ejection}

Once a toxin is eaten, it is in the animals best interest to quickly get rid of it. This can be accomplished through vomition or diarrhea (Kingsbury 1983). Sheep, goats, and cattle can and will vomit in response to eating toxins (Mullenax et al. 1966, Oehme and Barrett 1986). In ruminants, vomition is problematic because animals can aspirate the gut contents into their lungs, which can be fatal. Vomiting in ruminants is apparently sensitive to dose, as some toxic plant doses resulted in vomiting, whereas higher doses produced severe retching (Mullenax et al. 1966). Horses probably do not vomit except when near death, but commonly experience diarrhea (Oehme and Barrett 1986). Diarrhea aids in rapid elimination of toxins from the gut which reduces absorption. In some episodes of diarrhea, there is a decrease in intestinal motility, further reducing the absorption of toxins.

\section{Complex Formation}

Chemical reactions during ingestion may provide protection against the effects of some plant toxins. Some browsing herbivores secrete proline-rich proteins (PRPs) in their saliva which bind to ingested tannins reducing absorption and toxic effects (Robbins et al. 1991). Interestingly, salivary proteins from generalist herbivores, like bear and deer, bind several tannins whereas proteins from specialist feeders, like moose and beaver, bind only the tannin most commonly found in their diets (Hagerman and Robbins 1993). Cheeke (1998) speculated that physical forces during ingestion might allow animals to eat more of some plants containing highly volatile chemicals, such as sagebrush. Many terpenes may be lost through volatilization during chewing as when pygmy rabbits eat sagebrush (White et al. 1982). Increased chewing and ruminating has also been weakly associated with increased sagebrush consumption in sheep (Fraker 1999). Further, nasal tissue is capable of detoxifying some toxins through induction of the P450 enzyme system (Brattsten 1979). The inducible presence of a nasal detoxification system may facilitate the consumption of some noxious-smelling plants, like tansy ragwort (Senecio jacobaea L. ) consumed by goats and sheep (Cheeke 1998).

Some plant toxins are bound or sequestered by other ingested material that prevent toxic actions (Smith 1992). Geophagy (i.e., eating soil) is common among ungulates (Jones and Hanson 1985). Despite the widespread belief that mineral licks are sought by animals for their sodium content, it is more likely that other minerals (e.g., Ca, P, S) are more important (Jakle 1969, Jones and Hanson 1985). Detoxification pathways using sulphur are metabolically expensive and sulphur is usually in short supply (Brattsten 1979, McArthur et al. 1991). Thus, animals might practice geophagy to ingest sulphur. Moreover, mineral licks are often high in various clays (Jones and Hanson 1985) and some clays naturally bind to phytotoxins (Smith 1992). Geophagy may, therefore, deactivate some ingested plant toxins.

\section{Degradation by Microbes}

Ruminants often have a significant advantage over nonruminants when dealing with toxic plants because their large forestomach is well adapted to degrade or detoxify plant toxins (Oehme and Barrett 1986, Smith 1992, Pfister 1999). The nearly neutral $\mathrm{pH}$ of the rumen environment may modify a plant toxin or the toxin may be quickly diluted in the large volume (e.g., 225 to 265 liters for cattle) of the rumen. Of great significance for ingesting toxic plants is the massive number of rumen microbes which transform allelochemicals. Generally, for a rumen microbe to degrade a toxic plant compound, utilization of the compound must yield energy, and the microbial population must inhabit a particular rumen niche that allows it to survive when the toxin is not present (Weimer 1998). Microbial interactions with most phytotoxins lead to degradation or detoxification rendering the compounds inert or less detrimental. In some cases, however, rumen microbes can convert innocuous substances into toxic compounds such as the conversion of nitrite from the less toxic nitrate and the hydrolysis of cynogenic glycosides to toxic hydrogen cyanide (Allison 1978).

\section{Tissue-level Detoxification}

Once plant toxins are absorbed from the gut into the blood, they are often trans- 
ported to the liver (i.e., hepatic tissue). The liver primarily and secondarily the kidney, intestinal mucosa, lungs, and skin contain enzyme systems that metabolize (or alter) toxic compounds rendering them inert (McArthur et al 1991). This biotransformation involves several enzyme systems that generally yield polar compounds that can be excreted in urine or feces. For more details on detoxification in mammalian tissue see Brattsten (1979), McArthur et al. (1991), Smith (1992), or Launchbaugh (1996).

\section{Tolerance}

The last line of defense against the deleterious effects of plant allelochemicals occurs when the tissues vulnerable to damage by an allelochcemial become less sensitive or shielded in a process called physiological tolerance (Provenza et al.1992) or target-site insensitivity (Slansky 1992). Some herbivore species or individuals are more tolerant to specific toxic plants than others. For example, sheep can tolerate and detoxify more pyrrolizidine alkaloids than cattle and it therefore takes 5 times more tall larkspur to poison sheep compared to cattle (Olsen 1978). The superior tolerance of larkspur by sheep was thought to result from differences in ruminal metabolism; however, recent studies indicate that nicotinic acetylcholine (nAch) receptors of sheep bind the larkspur toxins much less avidly than do cattle nAch receptors (Stegelmeier et al. 1999).

\section{Influence of Previous Dietary Experience on Degradation, Detoxification, and Tolerance}

The ability of a compound to restrict plant quality or cause toxicosis depends partly on the dietary experience of the herbivore. With continued consumption of a plant containing a specific allelochemical, the animal may gain an ability to overcome its negative effects (Freeland and Janzen 1974). It is well known that enzyme systems in animal tissue can increase their detoxification capacity and efficiency in the repeated presence of a toxic substrate (Freeland and Janzen 1974, Brattsten 1979). In the case of tansy ragwort alkaloids, pretreatment of animals with the alkaloid jacobine results in elevated alkaloid detoxification activity (Miranda et al. 1980). Enhanced secretion and activity of chemical complexing substances has also been observed with the production of proline-rich saliva in response to high-tannin diets (Mehansho et al. 1985, Robbins et al. 1991).

Rumen microbes may also facilitate the ability of animals to adapt to diets high in phytotoxins. Microbial populations can change rapidly depending on the substrates available for degradation (Van Soest 1994). For example, ruminants that have dietary experience with oxalate-containing plants can tolerate levels of oxalates that would be lethal to nonadapted animals (James and Cronin 1974, Allison and Cook 1981). This protection from oxalates is attributed to oxalatedegrading rumen bacteria (Allison and Cook 1981). Likewise, dietary experience with nitrate-containing plants often leads to increased tolerance of nitrates attributed to increased populations of nitrite-degrading rumen microbes (Smith 1992). Exposure to fibrous diets at a young age has also been shown to improve fiber digestibility later in life (Distel et al. 1994). These "inducible defenses" could explain why herbivores often appear less sensitive to toxic or low quality plants with continued exposure. Nonetheless, adaptation does not develop to all toxins. The effects of many toxins are cumulative and animals get progressively more poisoned as they continue to ingest plant material containing these toxins.

\section{Influence of Animal Nutritional Status on Detoxification}

Detoxification of plant allelochemicals is a metabolically costly endeavor requiring nutrients and energy to alter toxins and maintain an acid-base equilibrium (Jessop and Illius 1997, Foley et al. 1999). Improving the nutritional state of the animal can often lead to increased rates of detoxification or decreased toxic effects (Freeland and Janzen 1974, Boyd and Campbell 1983), which can lead to increased intake of foods that contain toxins (Wang and Provenza 1996). Nutrient and energy availability can influence plant toxicity by altering rates of gastro-intestinal absorption and enzymatic detoxification, availability of co-substrates for detoxification, environmental conditions in the gastro-intestinal tract or body fluids, and capacity for tolerance (Boyd and Campbell 1983, Slansky 1992, Cheeke 1998). Dietary nutrients and energy are also required to maintain healthy rumen microbial populations (Van Soest 1994) important for detoxification of many plant allelochemicals (Allison 1978).

\section{Management Practices to Help Animals Contend with Anti- quality Attributes}

The most common approaches to reducing losses caused by anti-quality factors in forage plants are to change the plant community or grazing management strategy. Poisonous plants have been sprayed and mowed; shrublands with low forage value have been treated with herbicides, mechanically altered, or burned to remove the shrubs in favor of herbaceous forages; and, toxin-free forage varieties (e.g., endophyte-free fescue) have been developed and planted. Grazing periods have also been planned to minimize negative impacts of anti-quality factors. A more contemporary approach is to change the grazing animal, rather than the vegetation, to promote or encourage the animal's natural abilities to combat anti-quality attributes. A first step in creating herds or flocks of animals that can overcome antiquality attributes is to identify the most significant challenges that specific foraging situations present to herbivores. For example, in sagebrush-dominated communities, selecting or shaping animals with a significant ability to digest and detoxify monoterpene essential oils could greatly increase the amount of available forage. Once a foraging challenge is identified, management plans can be drafted to help animals meet this challenge.

\section{Offer Animals Proper Early Life Experiences}

Attempts to fashion animals with specific dietary attributes could begin at birth because early life experiences can strongly affect dietary habits later in life. Previous dietary experiences can influence the flavor preferences of animals (Nolte and Provenza 1992) and their ability to digest (Distel et al. 1994), detoxify (Distel and Provenza 1991, Robbins et al. 1991), and harvest (Ortega-Reyes and Provenza 1993) specific plants. Furthermore, experiences early in life often have a more lasting effect on consumption patterns than experiences later in life (Distel et al. 1994). Exposing animals to potentially troublesome plants in their youth may improve their ability to harvest, digest, and detoxify the plants when they mature. 


\section{Select Appropriate Livestock Species and Individuals}

It is well known that animal species differ in diet selection and intake. For example, when juniper consumption was compared for several rangeland herbivores in Texas, a clear pattern emerged of juniper intake as follows: deer>goats>sheep>cattle (Launchbaugh et al. 1997). A simple approach to making use of low quality or toxic forages is to select a livestock species that naturally makes good use of the target plant. For example, sheep can more safely graze larkspur-infested rangeland than cattle because they are more able to survive the toxic effects of larkspur (Olsen 1978, Pfister 1999). This simple concept is however often difficult for livestock producers to enact because changing the species being raised generally requires substantial changes in fencing, livestock handling equipment, management skills, knowledge, and philosophy. A more acceptable way to assemble groups of animals with desired dietary and digestive attributes might be to select an adapted breed within a species. Research on cattle (Herbel and Nelson 1966, Winder et al. 1996), sheep (Warren et al. 1984), goats (Warren et al. 1984, Pritz et al. 1997), and horses (Mariner and Alexander 1991) has revealed that breeds differ in dietary characteristics.

Individual variation within a breed may also create a basis for selecting animals to meet specific foraging challenges. Research on the behavioral, metabolic, and production effects of anti-quality factors have consistently revealed that animals vary significantly in their response to toxic or low quality plants. Furthermore, dietary differences between animals appear to be relatively consistent through a grazing season and between years (Launchbaugh et al. 1997). Most toxic plants with acute neurological effects (e.g., larkspurs; lupines; poison hemlock, Conium maculatum L.; broom snakeweed, Gutierrezia sarothrae [Pursh.] Britton \& Rusby; pine needles, Pinus spp.) exhibit wide variability in dose response when ingested by livestock (Pfister 1999). In future years, individual animals may be screened for response to anti-quality factors or susceptibility to toxins. For example, susceptibility to larkspur alkaloids could be tested using a muscle biopsy to indicate the binding affinity of the individual to toxic alkaloids. Using this or similar approaches, groups of animals may be assembled to access nutrients and withstand toxins in chemically defended plants.

\section{Breed Animals with Desired Attributes}

There is significant and growing evidence that the digestive and detoxification abilities of animals are heritable characteristics (Winder et al. 1995, Launchbaugh et al. 1999, Snowder et al. 2001). These inherited characteristics could influence diet selection and intake in several ways. Animals that have superior abilities to detoxify specific allelochemicals should be able to eat plants containing these phytochemicals and experience less negative feedback. A genetic basis for the detoxification abilities of animals is evidenced by the observation that detoxification of some drugs (e.g., hexobarbitol; Vessell 1968) and phytotoxins (e.g., flauoroacetates; Oliver et al. 1979, Mead et al. 1985) is strongly inherited. Dietary preferences are also influenced by inherited characteristics. Animals that are able to extract above average amounts of energy from specific plants, because of superior digestive abilities, should experience greater positive digestive feedback and form stronger and longer lasting preferences for these plants. The inheritance of enzyme systems involved in digestion is well documented (Velázquez and Bourges 1984). Differences in absorption of minerals (Green et al. 1989) and nutrients (Beaver et al. 1989) during digestion have been traced to animal breed and therefore indicate a genetic basis for digestion. Given the important role of digestive feedback in directing diet selection, it is not surprising that several studies have revealed significant inheritance values for diet patterns. A study of 60 young male Spanish goats in Texas showed dietary similarities between sire groups even though all goats were raised in a similar environment (Warren et al. 1983). A more recent study with Spanish $\mathrm{x}$ Boer cross goats revealed that the consumption of juniper by free-ranging goats had a heritability of .28 (C.A. Taylor, unpublished data). In other words, $28 \%$ of the variation in juniper consumption could be attributed to goat sire. Winder et al. (1995) reported significant heritability estimates for consumption of several range plants by Brangus cattle in New Mexico. Examination of big sagebrush consumption by more than 400 Rambouillet ewes over 2 years concluded that $25-28 \%$ of individual variation in sage consumption was heritable (Snowder et al. 2001). These studies point clearly to the possibility of breeding animals to overcome the challenges of specific anti-quality attributes.

\section{Offer Nutritional or Pharmaceutical Products to Aid in Digestion and \\ Detoxification}

The examination of anti-quality factors in plants often focuses on the biological mechanisms by which phytochemicals impact animal production. In several cases, these examinations led to the development of "antidotes" that help herbivores disarm specific allelochemicals or survive their biological assaults. For example, understanding the specific action of fescue alkaloids lead to the development of a compound (i.e., a dopamine antagonist) that blocks metabolic effects of the alkaloid (Aldrich et al. 1993). Supplementation of calcium can improve survival of sheep grazing halogeton (Halogeton glomeratus [Bieb.] C.A. May) infested rangeland because rumen microbes detoxify oxalates in halogeton by forming insoluble calcium oxalates that are excreted in the feces (James and Cronin 1974). Increased levels of dietary sulfur (Conn 1979) and vitamin $B_{12}$ (Brattsten 1979) have been shown to decrease the formation of hydrogen cyanide from cyanogenic glycoside containing plants. The toxic effects of larkspur alkaloids can be counteracted by injections of the cholinergic drug, physostigmine (Pfister et al. 1994). The complexing action of some allelochemicals, such as tannins, can be surmounted by supplementing animals with compounds such as polyethylene glycol that bind with the ingested phytochemicals before they can bind dietary and microbial proteins (McNabb et al. 1993). Simply improving the nutritional state of animals can often lead to increased rates of detoxification and decreased toxic effects (Freeland and Janzen 1974, Foley et al. 1995), which can lead to increases in intake of foods that contain toxins (Wang and Provenza 1996).

Development of vaccines to inoculate animals against specific plant toxins is becoming a reality. Recent work in Australia (Edgar et al. 1998) and in the U.S. (Lee and Stegelmeier, personal communication) indicate that commercial vaccines against some plant toxins (e.g., pyrrolizidine alkaloids) are feasible. One ancillary benefit of developing toxin-protein conjugates for vaccines is the concurrent use of such conjugates for immunoassays that will be useful for field-based assessment of toxin concentrations.

\section{Conclusions}

Foraging on rangelands and pasture poses several significant challenges to the herbivores. Grazing animals must utilize the nutritional value of plants to evade starvation, gain weight, and produce young while avoiding and negating the anti-quality attributes that are an implicit component 
of almost all forages. Livestock management in these situations can be significantly challenging. Developing grazing plans to minimize the impacts of plant anti-quality attributes requires an understanding of the behavioral and metabolic mechanisms that herbivores employ to extract nutrients from low quality or chemically-defended plants. New frontiers in forage and grazing management therefore lie in understanding the basics of animal behavior, digestion, and metabolism in relation to anti-quality characteristics. Understanding animal response to anti-quality factors in plants will, by necessity, focus on the consequences of consumption; a simple idea with immensely complex implications.

\section{Literature Cited}

Aldrich, C.B., M.T. Rhodes, J.L. Miner, M.S. Kerley, and J.A. Paterson. 1993. The effects of endophyte-infected tall fescue consumption and use of dopamine antagonist on intake, digestibility, body temperature, and blood constituents in sheep. J. Anim. Sci. 71:159-163.

Allison, M.J. 1978. The role of ruminal microbes in the metabolism of toxic constituents from plants, p. 101-118. In: R.F. Keeler, K.R. Van Kampen, and L.F. James (eds.) Effects of poisonous plants on livestock. Academic Press, New York, N.Y.

Allison, M.J. and H.M. Cook. 1981. Oxalate degradation by microbes of the large bowel of herbivores: The effect of dietary oxalate on ruminant adaptation. Sci. 212:675-676.

Arnold, G.W. 1981. Grazing behavior. p. 79104. In: F.H.W. Morley (ed.) Grazing animals. World animal science B1. Elsevier Sci. Pub. Co. New York. N.Y

Arnold, G.W. and J.L. Hill. 1972. Chemical factors affecting selection of food plants by ruminants. p. 71-101. In: J.B. Harborne (ed.) Phytochemical ecology. Academic Press, New York, N.Y.

Baptista., R. and K.L. Launchbaugh. 2001. Nutritive value and aversive feedback of honey mesquite leaves (Prosopis glandulosa) fed to sheep. J. Range Manage 54:(in press).

Beaver, E.D., J.E. Willliams, S.J. Miller, D.L. Hancock, S.M. Hannah, and D.L. O'Connor. 1989. Influence of breed and diet on growth, nutrient digestibility, body composition and plasma hormones of Brangus and Angus steer. J. Anim. Sci. 67:2415-2425.

Boyd, J.N. and T.C. Campbell. 1983. Impact of nutrition on detoxication. p. 287-306. In: J. Caldwell and W.B. Jakoby (eds.) Biological basis for detoxication. Academic Press, New York, N.Y.

Brattsten, L.B. 1979. Biochemical defense mechanisms in herbivores against plant allelochemicals, p. 200-270. In: G.A. Rosenthal and D.H. Janzen (eds.) Herbivores: Their interaction with secondary plant metabolites. Academic Press, New York, N.Y.
Burritt, E.A. and F.D. Provenza. 1989. Food aversion learning: Ability of lambs to distinguish safe from harmful foods. J. Anim. Sci. 67:1732-1739.

Burritt, E.A. and F.D. Provenza. 1991. Ability of lambs to learn with a delay between food ingestion and consequences given meals containing novel and familiar foods. Appl. Anim. Behav. Sci. 32:179-184.

Cheeke, P.R. 1998. Natural toxicants in feeds, forages, and poisonous plants. 2nd ed. Interstate Publ., Inc., Danville, Ill.

Conn, E.E. 1979. Cyanids and cyanogenic glycosids. p. 387-412. In: G.A. Rosenthal and D.H. Janzen (eds.) Herbivores: Their interaction with secondary plant metabolites. Academic Press, New York, N.Y.

Distel, R.A. and F.D. Provenza. 1991. Experience early in life affects voluntary intake of blackbrush by goats. J. Chem. Ecol. 17:431-450.

Distel, R.A., J.J. Villalba, and H.E. Laborde. 1994. Effects of early experience on voluntary intake of low quality roughage by sheep. J. Anim. Sci. 72:1191-1195.

Edgar, J.A., K.A. Than, A.L. Payne, N. Anderton, J. Baell, Y. Cao, P.A. Cockrum, A. Michalewicz, P.L. Stewart, and J.G. Allen. 1998. Towards a commercial vaccine against lupinosis. p. 196-200. In: T. Garland and A.C. Barr (eds.). Toxic plants and other natural toxicants. $\mathrm{CAB}$ International, Wallingford, Oxon, UK.

Foley, T.D.A., S. McLean, and S.J. Cork. 1995. Consequences of biotransformation of plant secondary metabolites on acid-base metabolism in mammals: A final common pathway? J. Chem. Ecol. 21:721-743.

Foley, W.J., G.R. Iason, and C. McArthur. 1999. Role of plant secondary metabolites in the nutritional ecology of mammalian herbivores: How far have we come in 25 years? Symp. on the Nutr. Ecol. of Herbivores: An Integration. San Antonio, Tex April 11-16, 1999.

Fraker, M.J. 1999. Examination of digestive and behavioral mechanisms to explain individual variation in sagebrush consumption by sheep. M.S. Thesis. Univ. of Idaho, Moscow, Ida.

Freeland, W.J. 1991. Plant secondary metabolites: Biochemical coevolution with herbivores. p. 61-81. In: R.T. Palo and C.T. Robbins (eds.) Plant defenses against mammalian herbivory. CRC Press, Boca Raton, Fla.

Freeland, W.J. and D.H. Janzen. 1974. Strategies in herbivory by mammals: The role of plant secondary compounds. Amer. Nat. 108:269-289.

Freeland, W.J., P.H. Calcott, and L.R. Anderson. 1985. Tannin and saponin: Interaction in herbivore diets. Biochem. Ecol. Syst. 13:189-193.

Garcia, J. 1989. Food for Tolman: Cognition and cathexis in concert. p. 45-85. In: T. Archer and L. Nilsson (eds.) Aversion, avoidance and anxiety. Erlbaum. Hillsdale, N.J.

Glendinning, J.I. 1994. Is the bitter rejection response always adaptive? Physiol. Behav. 56:1217-1227.
Grant, V.L. 1987. Do conditioned taste aversions result from activation of emetic mechanisms? Psychopharmacology. 93:405-415.

Green, L.W., J.F. Baker, and P.F. Hardt. 1989. Use of animal breeds and breeding to overcome the incidence of grass tetany: A review. J. Anim Sci. 67:3463-3469.

Hagerman, A.E. and C.T. Robbins. 1993. Specificity of tannin-binding salivary proteins relative to diet selection by mammals. Can. J. Zool. 71:628-633.

Herbel, C.H. and A.B. Nelson. 1966. Species preference of Hereford and Santa Gertrudis cattle on a southern New Mexico range. J. Range Manage. 19:177-181.

Herms, D.A. and W.J. Mattson. 1992. The dilemma of plants: To grow or defend. Quart. Rev. Biol. 67:283-313.

Jakle, J.J. 1969. Salt on the Ohio Valley frontier, 1770-1820. Ann. Assoc. Amer. Geogr. 59:687-709.

James, L.F. and E.H. Cronin. 1974. Management practices to minimize death losses of sheep grazing halogeton-infested rangeland. J. Range Manage. 27:424-426.

Jessop, N.S. and A.W. Illius. 1997. Modeling animal responses to plant toxicants. $p$. 243-253. In: J.P.F. D’Mello (ed.) Handbook of plant and fungal toxicants. CRC Press, Boca Raton, Fla.

Jones, R.L. and H.C. Hanson. 1985. Mineral licks, geophagy, and biogeochemistry of North American ungulates. Iowa State Univ. Press, Ames, Iowa.

Kingsbury, J.M. 1983. The evolutionary and ecological significance of plant toxins. $p$. 675-706. In: R.F. Keeler and A.T. Tu (eds.) Handbook of natural toxins. Marcel Dekker, Inc., N.Y.

Lane, M.A., M.H. Ralphs, J.D. Olsen, F.D. Provenza, and J.A. Pfister. 1990. Conditioned taste aversion: Potential for reducing cattle loss to tall larkspur. J. Range Manage. 43:127-131.

Launchbaugh, K.L. 1996. Biochemical aspects of grazing behavior. p. 159-184. In: J. Hodgson and A.W. Illius (eds.) The ecology and management of grazing systems. CAB International, Wallingford, Oxon, U.K.

Launchbaugh, K.L. and F.D. Provenza. 1993. Can plants practice mimicry to avoid grazing by mammalian herbivores? Oikos. 66:501-504.

Launchbaugh, K.L. and F.D. Provenza. 1994. The effect of flavor concentration and toxin dose on the formation and generalization of flavor aversions in lambs. J. Anim. Sci. 72:10-13.

Launchbaugh, K.L., F.D. Provenza, and E.A. Burritt. 1993. How herbivores track variable environments: Response to variability of phytotoxins. J. Chem. Ecol. 19:1047-1056.

Launchbaugh, K.L, J.W. Walker, and C.A. Taylor. 1999. Foraging behavior: Experience or inheritance. p.28-35. In: K.L. Launchbaugh, K.D. Sanders, and J.C. Mosley. (eds.) Grazing behavior of livestock and wildlife. Idaho Forest, Wildlife, and Range Exp. Sta. Bull. No. 70. Moscow, Ida 
Launchbaugh, K.L., C.A. Taylor, E. Straka, and R.K. Pritz. 1997. Juniper as forage: An unlikely candidate? In: 1997 Juniper Symposium. Texas Agr. Exp. Station. Tech Rep. 97-1.

Marinier, S.L. and A.J. Alexander. 1991. Selective grazing behavior in horses: Development of methodology and preliminary use of tests to measure individual grazing abilities. Appl. Anim. Behav. Sci. 30:203--221.

McArthur, C., A.E. Hagerman, and C.T. Robbins. 1991. Physiological strategies of mammalian herbivores against plant defenses. p. 104-131. In: R.T. Palo and C.T. Robbins (eds.) Plant defenses against mammalian herbivory. CRC Press, Boca Raton, Fla.

McNabb, W.C., G.C. Waghorn, T.N. Barry, and I.D. Shelton. 1993. The effect of condensed tannins in Lotus pedunculatus on the digestion and metabolism of methionine, cystine and inorganic sulphur in sheep. British J. Nutr. 70:647-661.

Mead, R.J., A.J. Oliver, D.R. King, and P.H. Hubach. 1985. The co-evolutionary role of flauroacetate in plant-animal interactions in Australia. Oikos 44:55-60.

Mehansho, H., S. Clements, B.T. Shears, S. Smith, and D.M. Carlson. 1985. Induction of proline-rich glycoprotein synthesis in mouse salivary glands by isoproternol and by tannins. J. Biol. Chem. 260:4418-4423.

Meyer, M.W. and W.H Karasov. 1991. Chemical aspects of herbivory in arid and semiarid habitats. p.167-188. In: R.T. Palo and C.T. Robbins. (eds.) Plant defenses against mammalian herbivory. CRC Press, Boca Raton, Fla.

Miranda, C.L., P.R. Cheeke, and D.R. Buhler. 1980. Effect of pyrrolizidine alkaloids from tansy ragwort (Senecio jacobaea) on hepatic drug-metabolizing enzymes in male rats. Biochem. Pharmacol. 29:2645-2649.

Mirza, S.N. and F.D. Provenza. 1990. Preference of the mother affects selection and avoidance of foods by lambs differing in age. Appl. Anim. Behav. Sci. 28:255-263.

Mirza, S.N. and F.D. Provenza. 1994. Socially induced food avoidance in lambs: Direct or indirect material influence. J. Anim. Sci. 72:899-902.

Mullenax, C.H., W.B. Buck, R.F. Keeler, and W. Binns. 1966. Stimulating eructation and vomition in normal and bloated ruminants with alkaloidal extracts from Veratrum spp. Am. J. Vet. Res. 27:211-222.

Nolte, D.L. and F.D. Provenza. 1992. Food preferences in lambs after exposure to flavors in milk. Appl. Anim. Behav. Sci. 32:381-389.

Oehme, F.W. and D.S. Barrett. 1986. Veterinary gastrointestinal toxicology. p. 464-513. In: K. Rozman and O. Hanninen (eds.) Gastrointestinal toxicology. Elsevier Pub. Co., Amsterdam.

Oliver, A.J., D.R. King, and R.J. Mead. 1979. Flauroacetate tolerance, a genetic marker in some Australian mammals. Aust J. Zool. 27:363-72.
Olsen, J.D. 1978. Tall larkspur poisoning in cattle and sheep. J. Amer. Vet. Med. Assoc. 173:762-765.

Ortega-Reyes, L. and F.D. Provenza. 1993. Amount of experience and age affect the development of foraging skills of goats browsing blackbrush (Coleogyne ramosissima). Appl. Anim. Behav. Sci. 36:169-183.

Owen, J.B. 1992. Genetic aspects of appetite and food choice in animals. J. Agr. Sci. (Camb.) 119:151-155.

Pfister, J.A. 1999. Behavioral strategies for coping with poisonous plants. p. 45-59. 1999. In: K.L. Launchbaugh, K.D. Sanders, and J.C. Mosley. (eds.) Grazing behavior of livestock and wildlife. Idaho Forest, Wildlife, and Range Exp. Sta. Bull. No. 70. Moscow, Ida.

Pfister, J.A., and D.R. Gardner. 1999. Consumption of low larkspur (Delphinium nuttallianum) by cattle. J. Range Manage. $52: 378-384$

Pfister, J.A., J.B. Astorga, K.E. Panter, and R.J. Molyneux. 1993. Maternal locoweed exposure in utero and as a neonate does not disrupt taste aversion learning in lambs. Appl. Anim. Behav. Sci. 36:159-167.

Pfister, J.A., G.D. Manners, D.R. Gardner, and M.H. Ralphs. 1994. Toxic alkaloid levels in tall larkspur (Delphinium barbeyi) in western Colorado. J. Range Manage. 47:355-358

Pfister, J.A., G.D. Manners, D.R. Gardner, K.W. Price, and M.H. Ralphs. 1996. Influence of alkaloid concentration on acceptability of tall larkspur (Delphinium spp.) to cattle and sheep. J. Chem. Ecol. 22:1147-1168.

Pfister, J.A., G.D. Manners, M.H. Ralphs, Z.X. Hong, and M.A. Lane. 1988. Effects of phenology, site and rumen fill on tall larkspur consumption by cattle. J. Range Manage. 41:509-514

Pfister, J.A., F.D. Provenza, G.D. Manners, D.R. Gardner, and M.H. Ralphs. 1997. Tall larkspur ingestion: Can cattle regulate intake below toxic levels? J. Chem. Ecol. 23:759-777.

Prins, H.H.T. and J.H. Beekman. 1989. A balanced diet as a goal of grazing: The food of the Manyara buffalo. African. J. Ecol. 27:241-259.

Pritz, R.K., K.L. Launchbaugh, and C.A. Taylor Jr. 1997. Effects of breed and dietary experience on juniper consumption by goats. J. Range Manage. 50:600-606.

Provenza, F.D. 1995. Postingestive feedback as an elementary determinant of food preference and intake in ruminants. J. Range Manage. 48:2-17.

Provenza, F.D. 1996. Acquired aversions as the basis for varied diets of ruminants foraging on rangelands. J. Anim. Sci. 74:2010-2020.

Provenza, F.D. and E.A. Burritt. 1991. Socially induced diet preference ameliorates condition food aversion in lambs. Appl. Anim. Behav. Sci. 31:229-236.

Provenza, F.D., B.R. Kimball, and J.J. Villalba. 1999. Roles of odor, taste, and toxicity in the food preferences of lambs; implications for mimicry in plants. Oikos 88:424-432.
Provenza, F.D., J.J. Lynch, and J.V. Nolan. 1993. The relative importance of mother and toxicosis in the selection of foods by lambs. J. Chem. Ecol. 19:313-323.

Provenza, F.D., J.A. Pfister, and C.D. Cheney. 1992. Mechanisms of learning in diet selection with reference to phytotoxicosis in herbivores. J. Range Manage. 45:36-45.

Provenza, F.D., J.J. Lynch, E.A. Burritt, and C.B. Scott. 1994b. How goats learn to distinguish between novel foods that differ in postingestive consequences. J. Chem. Ecol. 20:609-624.

Provenza, F.D., J.J. Villalba, C.D. Cheney, and S.J. Werner. 1998. Self-organization of foraging behavior: From simplicity to complexity without goals. Nutr. Res. Rev. 11:199-222.

Provenza, F.D., L. Ortega-Reyes, C.B. Scott, J.J. Lynch, and E.A. Burritt. 1994a. Antiemetic drugs attenuate food aversions in sheep. J. Anim. Sci. 72:1989-1994.

Provenza, F.D., E.A. Burritt, T.P. Clausen, J.P. Bryant, P.B. Reichardt, and R.A. Distel. 1990. Conditioned flavor aversion: A mechanism for goats to avoid condensed tannins in blackbrush. Amer. Nat. 136:810-828.

Ralphs, M.H. and C.D. Cheney. 1993. Effects of propionate infusion and dietary energy on dry matter intake of sheep. J. Anim. Sci 71:373-379.

Reese, J.C. 1979. Interactions of allelochemicals with nutrients in herbivore food. $p$. 309-330. In: G.A.. Rosenthal and D.H. Janzen (eds) Herbivores: Their interactions with secondary plant metabolites. Academic Press, New York, N.Y.

Rhoades, D.F. 1979. Evolution of plant chemical defense against herbivores. p. 4-55 In: G.A. Rosenthal and D.H. Janzen (eds.) Herbivores: Their interaction with secondary plant metabolites. Academic Press, New York, N.Y.

Robbins, C.T., A.E. Hagerman, P.J. Austin, C. McArthur, and T.A. Hanley. 1991. Variation in mammalian physiological responses to a condensed tannin and its ecological implications. J. Mammal. 72:480-486.

Sclafani, A. 1991. The hedonics of sugar and starch. p. 59-87. In: R.C. Bolles (ed.) The hedonics of taste. Lawrence Erlbaum Assoc., Hillsdale, N.J.

Slansky, F. 1992. Allelochemical-nutrient interactions in herbivore nutritional ecology. p. 135-175. In: G.A. Rosenthal and M.R. Berenbaum (eds) Herbivores: Their interactions with secondary plant metabolites, Vol II: Evolutionary and Ecological Processes. Academic Press, New York, N.Y.

Smith, G.S. 1992. Toxification and detoxification of plant compounds by ruminants: An overview. J. Range Manage. 45:25-30. 
Smith, E.R., K.L. Launchbaugh, and T.C. Griggs. 1999. Does energy feedback from carbohydrates affect dietary preferences in grazing animals? p. 177 (abst.) In: K.L. Launchbaugh, K.D. Sanders, and J.C. Mosley. (eds.) Grazing behavior of livestock and wildlife. Idaho Forest, Wildlife, and Range Exp. Sta. Bull. No. 70. Moscow, Ida

Smotherman, W.P. 1982. Odor aversion learning by the rat fetus. Physiol. and Behav. 29:769-771.

Snowder, G.D., J.W. Walker, K.L. Launchbaugh, and L.D. Van Vleck. 2001. Genetic and phenotypic parameters for dietary selection of mountain big sagebrush (Artemisia tridentata spp. vaseyana) in Rambouillet sheep. J. Anim. Sci. 79:486-492.

Stegelmeier, B.L., J.A. Edgar, S.M. Colegate, D.R. Gardner, T.K. Schoch, R.A. Coulombe, and R.J. Molyneux. 1999. Pyrrolizidine alkaloid plants, metabolism and toxicity. J. Natural Toxins 8:95-116.

Thorhallsdottir, A.G., F.D. Provenza, and D.F. Balph. 1990a. Ability of lambs to learn about novel foods while observing or participating with social models. Appl. Anim. Behav. Sci. 25:25-33.

Thorhallsdottir, A.G., F.D. Provenza, and D.F. Balph. 1990b. The role of mother in the intake of harmful foods by lambs. Appl. Anim. Behav. Sci. 25:35-44.

VanSoest, P.J. 1994. Refractory and inhibitory substances. p. 118-138. In: Nutritional ecology of the ruminant, 2nd ed. Cornell Univ. Press, Ithaca, N.Y.

Velázquez, A. and H. Bourges. 1984. Genetic factors in nutrition. Academic Press, New York, N.Y.
Vessell, E.S. 1968. Genetic and environmental factors affecting hexobarbital metabolism in mice. Ann. New York. Acad. Sci. 151:900-911.

Villalba, J.J. and F.D. Provenza. 1996. Preference for flavored wheat straw by lambs conditioned with intraruminal administrations of sodium propionate. J. Anim. Sci. 74:2362-2368.

Villalba, J.J. and F.D. Provenza. 1997a. Preference for wheat straw by lambs conditioned with intraruminal infusions of starch. Br. J. Nutr. 77:287-297.

Villalba, J.J. and F.D. Provenza. 1997b. Preference for flavored wheat straw by lambs conditioned with intraruminal infusions of acetate and propionate. J. Anim. Sci. 75:2905-2914.

Villalba, J.J. and F.D. Provenza. 1997c. Preference for flavoured foods by lambs conditioned with intraruminal administration of nitrogen. Br. J. Nutr. 78:545-561.

Villalba, J.J. and F.D. Provenza. 1999. Nutrient-specific preferences by lambs conditioned with intraruminal infusions of starch, casein, and water. J. Anim. Sci. 77:378-387.

Villalba, J.J. and F.D. Provenza. 2000. Roles of novelty, generalization and postingestive feedback in the recognition of foods by lambs. J. Chem. Ecol. (in press)

Villalba, J.J., F.D. Provenza, and J. Rogosic. 1999. Preference for flavored wheat straw by lambs conditioned with intraruminal infusions of starch administered at different times after straw ingestion. J. Anim. Sci. 77:3185-3190

Wang, J. and F.D. Provenza. 1996. Food deprivation affects preference of sheep for foods varying in nutrients and a toxin. J. Chem. Ecol. 22:2011-2021.
Wang, J. and F.D. Provenza. 1997. Dynamics of preference by sheep offered foods varying in flavors, nutrients, and a toxin. J. Chem. Ecol. 23:275-288.

Warren, L.E., J.M. Shelton, and D.N. Ueckert. 1983. Genetic influence on foraging behavior (diet selection) of ruminants (sheep and goats). Small Ruminant Collaborative Research Support Program. Tech. Rep. Series. No. 32. Texas Agr. Exp. Sta., San Angelo, Tex.

Warren, L.E., D.N. Ueckert, and J.M. Shelton. 1984. Comparative diets of Rambouillet, barbado, and karakul sheep and Spanish and angora goats. J. Range Manage. 37:172-179.

Weimer, P.J. 1998. Manipulating ruminal fermentation: A microbial ecological perspective. J. Anim. Sci. 76:3114-3122.

Westoby, M. 1978. What are the biological bases of varied diets? Amer. Nat. 112:627-631.

Winder, J.A., D.A. Walker, and C.C. Bailey. 1995. Genetic aspects of diet selection in the Chihuahuan desert. J. Range Manage. 48:549-553.

Winder, J.A., D.A. Walker, and C.C. Bailey. 1996. Effect of breed on botanical composition of cattle diets on Chihuahuan desert range. J. Range Manage. 49:209-214.

White, S.M., B.L. Welch, and J.T. Flinders. 1982. Monoterpenoid content of pygmy rabbit stomach ingesta. J. Range Manage. 35:107-109. 